\title{
Solens mystiske godnat - det flygtige gronne glimt
}

Af geolog Morten L. Hjuler, GeologiskNyt

Når solen går til ro bag horisonten, sender den en sjælden gang en sidste kort hilsen i form af et grønt glimt. Selvom fænomenet har en videnskabelig forklaring, er det også omgærdet af mystik...

Kendte forfattere som Jules Verne, Rider Haggard og Victoria Holt har peppet deres skønlitterære værker op med det besynderlige, grønne glimt, og med sine visuelle kvaliteter er det ikke underligt, at det grønne glimt har fundet vej til filmen.

I den vildt fabulerende filmtrilogi, Pirates of the Caribbean, præsenteres man for et broget piratunivers domineret af den uberegnelige pirat, Jack Sparrow, hvis dyssociale personlighedsforstyrrelser kæmper om skærmpladsen med alskens overnaturlige væsener og fænomener. Tag nu fx skibet Den Flyvende Hollcender, som kommer farende op fra havets dyb ledsaget af et grønt glimt. Ifølge filmens mytologi tilkendegiver det grønne glimt, at en sjæl er undsluppet fangenskabet i Davy Jones locker - dvs. Den Flyvende Hollcenders arrest. Ikke nogen videre plausibel forklaring, videnskabeligt set! Men godt for filmen, godt for Jack Sparrow og godt for Sparrow-fans...

\section{Atmosfæren er et prisme}

Hvis vi forlader fantasiens overdrev, leverer atmosfæren en anderledes videnskabelig forklaring på fænomenet det grønne glimt. Atmosfæren fungerer nemlig som et gigantisk prisme, som bryder solens stråler efter bestemte retningslinier.

I den tætte del af jordens atmosfære, de nederste ca. $40 \mathrm{~km}$, vil sollyset kollidere med atmosfærens molekyler og støvpartikler og blive afbøjet. De kortbølgede blå stråler afbøjes mest, de langbølgede røde stråler mindst. Farverækkefølgen er ordnet med violet, blåt, og grønt øverst efterfulgt af gult, orange og rødt nederst.

Da det blå lys spredes mest, rammer det os ved jordoverfladen fra alle sider, hvorfor vi opfatter himlen - i retninger langt væk fra solen - som blå. Eftersom de korte blå bølgelængder er spredt væk fra det direkte sollys, ser solen gul ud. Om aftenen og morgenen, når solen står lavt, skal sollyset bevæge sig væsentligt længere gennem atmosfæren, hvilket betyder, at også lys med længere bølgelængder - eller rødere lys bliver spredt. Solen og himlen omkring solen opfattes nu som rød.

\section{Det grønne glimt}

Vi er nu fremme ved sagens kerne. Når solen er ved at være gået ned, vil de røde nuancer forsvinde bag horisonten, mens de violette, blå og grønne nuancer forbliver synlige. $\mathrm{Nu}$ skal de violette og blå nuancer sorteres fra, men det kræver helt særlige forhold.

Først og fremmest skal man have frit udsyn til en skyfri horisont, og atmosfæren skal være meget klar og rolig. Det gør umiddelbart havet til det perfekte observationspunkt. Dertil kommer en distinkt lagdeling af atmosfæren i temperaturzoner, hvis laggrænser muliggør spredning af de violette, blå og grønne farver. Med reduceret spredning af de korteste bølgelængder sorteres violet og blå fra, og kun den grønne farve er tilbage.

Men tiden er knap og man skal være opmærksom! Solen er næsten forsvundet bag horisonten, når det grønne glimt indtræffer som en grønfarvning af solskivens øverste del - og det varer typisk kun 2-3 sekunder. I sjældne tilfælde kan luftspejlinger forlænge glimtets levetid, selv efter at solen er forsvundet bag horisonten.

I mere sjældne tilfælde kan tilstedeværelsen af en dis få det grønne glimt til at danne en få grader høj stråle, hvilket minder mere om de voldsomme grønne glimt fra Pirates of the Caribbean. Men den slags optiske betragtninger tynger dog næppe Jack Sparrow. Han er p.t. på jagt efter ungdommens kilde! 